\title{
A racionalização da vida como processo histórico: crítica à racionalidade econômica e ao industrialismo
}

\section{The rationalization of life as historic process: a critique of economic rationality and industrialization}

Valdir Fernandes ${ }^{1}$

\begin{abstract}
Resumo
O tema deste artigo insere-se nos estudos teóricos sobre o conceito de racionalidade e na crítica à racionalidade econômica. Discute a racionalização da vida como processo histórico, tendo como fio condutor o conceito de racionalidade, partindo da noção aristotélica de razão e passando pelas análises de Max Weber, Karl Mannheim, autores da Escola de Frankfurt, Ivan Illich, André Gorz, Karl Polanyi e Guerreiro Ramos. Com base nesse quadro teórico, constrói-se a crítica à racionalidade econômica, sobre a qual se fundam o atual processo de desenvolvimento e suas mazelas e a própria noção de progresso.
\end{abstract}

Palavras chaves: racionalidade instrumental e econômica; capitalismo; industrialismo; problemática socioambiental

Abstract

This article analyzes theoretical studies about the concept of rationality and criticizes economic rationality. It discusses the rationalization of life as a historic process, guided by the principal of rationality based on the Aristotelian notion of reason and extending through analyses by Max Weber, Karl Mannheim, the Frankfurt School, Ivan Illich, André Gorz, Karl Polanyi and Guerreiro Ramos. Based on this theoretical framework, it constructs a criticism of economic rationality upon which is based the current process of development and its difficulties, and the very notion of progress.

Key-words: instrumental and economic rationality; capitalism; industrialization; socio-environmental issues;

\section{Introdução}

De acordo com Habermas (1994), quando se quer explicar o nascimento das sociedades modernas, do ponto de vista histórico e metodológico, o processo de racionalização da vida é um fenômeno-chave. No mesmo sentido, Horkheimer (2002, p. 106) afirma que: "a completa transformação do mundo em um mundo mais de 'meios' do que de 'fins' é em si mesma a conseqüência do desenvolvimento histórico da produção". Esse desenvolvimento só pôde ocorrer, porém, como consequiência da lógica formal, a grande escola da uniformização iluminista, e dos seus esquemas de calculabilidade do mundo (ADORNO; HORKHEIMER, 2000). Por conseguinte, o que ocorreu no Ocidente não foi outra coisa que um processo de racionalização dos sistemas produtivos, com conseqüências em todos os aspectos da vida, do econômico ao religioso.

A racionalidade é o que determina a ação social. $\mathrm{O}$ conceito de racionalidade é, desse modo, constitutivo e elemento central do conceito de ação social. Weber (1996) demonstrou isto de modo peculiar em $A$ ética protestante e o espírito do capitalismo. Com sua Sociologia 'Compreensiva', usando o recurso metodológico dos 'tipos ideais', Weber (1999) previne, porém, que seu procedimento não deve ser interpretado como um

\footnotetext{
${ }^{1}$ Graduado em Ciências Sociais pela Universidade Federal de Santa Catarina (2000) e mestre em Engenharia Ambiental pela Universidade Federal de Santa Catarina (2002), doutor em Engenharia Ambiental pela Universidade Federal de Santa Catarina (2007). Atualmente realiza estágio de Pós-Doutorado no Programa de Saúde Ambiental da Faculdade de Saúde Pública da Universidade de São Paulo (USP). Endereço: Faculdade de Saúde Pública - USP - Departamento de Saúde Ambiental. Av. Dr. Arnaldo, 715 - $1^{\circ}$ andar - São Paulo - SP - Brasil - CEP 01246-904 - E-mail: v.fernandes@usp.br 
preceito racionalista, senão apenas como conveniência metodológica. Isto é, não há como compreender a vida e a ação social apenas por um viés racional da relação entre meios e fins, este como único determinante das ações efetivas. Há, portanto, outras racionalidades e também muito de irracional no mundo a ser compreendido. Nesse sentido, ele distingue as tipologias de racionalidade que determinam a ação social e/ou individual em quatro categorias, como se segue:

A ação social pode ser determinada: 1) de modo racional referente a fins: por expectativas quanto ao comportamento de objetos do mundo exterior e de outras pessoas, utilizando essas expectativas como 'condições' ou 'meios' para alcançar fins próprios, ponderados e perseguidos racionalmente, como sucesso; 2) de modo racional referente a valores: pela crença consciente no valor - ético, estético, religioso ou qualquer que seja sua interpretação - absoluto e inerente a determinado comportamento como tal, independentemente dos resultados; 3) de modo afetivo, especialmente emocional: por afetos ou estados emocionais atuais; 4) de modo tradicional: por costume arraigado. (WEBER, 1999, p. 15, grifo do autor)

Um comportamento racional, assim, não é desprovido de 'sentido' - aquele dado pelo indivíduo ou pelo grupo social à sua ação -, ao contrário, quanto mais um indivíduo ou uma sociedade é capaz de atribuir um 'sentido' às suas ações, tanto mais racionais estas serão no sentido lato.

Weber pondera que o comportamento estritamente 'tradicional' ou estritamente 'afetivo' encontra-se no meio termo entre a razão em senso 'valorativo' e a razão referente a 'fins'. A racionalidade de 'valor' constitui-se de ações praticadas cujas consequiências previsíveis não são consideradas porque se dão com base em convicções éticas, religiosas, morais ou estéticas. De acordo com Ramos (1989), a racionalidade de valor é apenas "uma nota de rodapé" na obra de Weber e, por isso, não desempenha um papel sistemático nos seus estudos. De fato, Weber mesmo justifica que a ação racional referente a valores somente é uma preocupação sua na medida em que encontra ações humanas que se orientam por ela, o que, segundo ele, ocorre de maneira muito diversificada. A sua preocupação principal, portanto, é a racionalidade 'referente a fins'. Segundo Weber (1999, p. 16, grifo do autor): "age de maneira racional referente a fins quem orienta sua ação pelos fins, meios e conseqüências secundárias, 'ponderando' racionalmente tanto os meios em relação às consequiências secundárias, assim como os diferentes fins possíveis entre si”. Conseqüientemente, a ação referente a fins - em sentido estrito e dentro do recurso metodológico de 'tipos ideais' - não é uma ação de modo 'afetivo' nem 'tradicional'. No entanto, para Weber (1999, p. 16), "a decisão entre fins e conseqüências concorrentes e incompatíveis, por sua vez, pode ser orientada racionalmente com referência a valores". Trata-se, em outras palavras, de uma submissão da racionalidade referente a fins (Zweckrationalität - ética da responsabilidade) à racionalidade de valor (Wertrationalität - ética da convicção), mesmo se, do ponto de vista da racionalidade referente a fins, a racionalidade de valor tiver sempre um caráter irracional, visto que está baseada em valores não tangíveis, como os religiosos, os morais, os éticos e os estéticos. Todavia, segundo Weber, só muito raramente a ação social se dá exclusivamente orientada por uma ou por outra destas duas racionalidades. Em geral, as ações comportam as duas racionalidades, embora, como ele demonstra - e se explicitará no decorrer deste artigo -, no capitalismo, historicamente houve o predomínio da racionalidade referente a fins - que passamos a denominar, de acordo com a literatura atual, como racionalidade instrumental - sobre a racionalidade de valor.

Para Ramos (1989), embora numa leitura rápida essa análise de Weber aparente ser laudatória, seria um erro atribuir-lhe qualquer compromisso dogmático com a racionalidade gerada pelo capitalismo, ou mesmo chamála de superficial - ao contrário, é essencialmente profunda e crítica. Além disso, a neutralidade em face dos valores como posição metodológica sempre foi a sua principal marca (RAMOS, 1989), e sua tarefa de definir o 'espírito do capitalismo' tomando por base o estudo da ética protestante é o melhor exemplo de neutralidade e rigor metodológico.

O conceito de racionalidade proposto por Weber não é um instrumento de intervenção social. Tampouco uma proposição ideológica ou um conjunto de postulados visto como um modelo a ser aplicado, ou um conjunto de 
diretrizes tal qual o caso de conceitos como o de desenvolvimento sustentável. ${ }^{1}$ Pelo contrário, trata-se de um conceito analítico, uma categoria de análise que funciona como lente, através da qual é possível enquadrar, 'ver', refletir e compreender a ação social, suas motivações, seus valores, seus desdobramentos e funcionalidades. Evidentemente que, para ser aplicado como categoria de análise, qualquer conceito anteriormente formulado precisa ser atualizado, respeitando-se o universo semântico da época, assim como o clima cultural e suas particularidades. Essas atualizações, e até mesmo ressignificações, devem respeitar, porém, igualmente a semântica e a ontologia do conceito, de forma a não distorcer a sua natureza, tornando-o uma hipóstase $^{2}$ no sentido de justificar - um hábito corrente - posições ideológicas e convicções.

É importante ressaltar também que Weber sempre foi um antideterminista e avesso à explicação de qualquer fenômeno como monocausal - portanto, exclui-se de suas intenções qualquer objetivo nesse sentido. Uma de suas preocupações em A ética Protestante e o Espírito do Capitalismo reside em justamente refutar o determinismo econômico preponderante nas discussões teóricas da sua época - e o faz mostrando que outras esferas sociais (a religião, por exemplo) também poderiam ser determinantes da esfera econômica (COHN, 1989). Outra ressalva importante é que o fato de Weber ter 'encontrado' o 'espírito do capitalismo' na ética protestante não significa absolutamente que este seja uma exclusividade de grupos religiosos, de puritanos, de calvinistas, de americanos do norte ou de europeus. Exclui-se também o determinismo nesse sentido. O que Weber demonstra é que, nesses grupos especificamente, a racionalização da vida, ${ }^{3}$ provocada pela ascese ${ }^{4}$ religiosa, propiciou como consequiência direta um incremento na rapidez e na sofisticação do desenvolvimento econômico - dadas certas condições que ele mesmo expõe -, que sinteticamente exploramos na seção 4.1 deste artigo.

Além das discussões acerca do grau de influência que a vocação e a ascética protestantes significaram efetivamente para que o capitalismo atingisse determinado estágio, é importante a extraordinária sistematização da ação social, feita por Weber, que possibilitou a compreensão da racionalidade predominante no desenvolvimento do capitalismo, ou seja, do 'espírito do capitalismo'. Com base nessa sistematização, tornouse compreensível o significado da racionalidade instrumental - a construção de meios com vistas a determinados fins - para o desenvolvimento do capitalismo e do estilo de vida por ele inaugurado. Por sua vez, um conceito de racionalidade referente a fins só foi possível com a emergência do capitalismo e da sociedade de mercado, pois, como observa Ramos (1989), antes disso a racionalidade era sempre revestida de nuances éticas. Com o surgimento da sociedade de mercado, a racionalidade foi transformada em capacidade de cálculo utilitário de consequiências, tornando-se, por conseguinte, como desvela Weber (1996), em 'espírito do capitalismo'. Afora a ascética protestante, é de fundamental importância também a diferenciação feita por Weber (1999) $)^{5}$, em Economia e Sociedade, entre "gestão econômica" e "ação economicamente orientada", da qual trataremos na seção 8 deste artigo.

Não apenas Weber, mas também Simmel (1977), ${ }^{6}$ em a Filosofia do dinheiro, traz a discussão sobre a racionalização e a instrumentalização da vida, e sobre a sobreposição da racionalidade instrumental em relação aos outros tipos de racionalidade. Pare ele, o dinheiro é o símbolo da época moderna, que, por sua vez, caracteriza-se pela impessoalidade dos relacionamentos humanos, cada vez mais frios e descompromissados.

\footnotetext{
${ }^{1}$ O conceito de desenvolvimento sustentável é uma proposição que prevê a sustentabilidade em várias dimensões: ambiental, social, econômica, política (ver Sachs, 1986; 1993).

${ }^{2}$ Ficção ou abstração falsamente considerada como real.

${ }^{3}$ A organização metódica da vida na busca pela salvação provocou a construção de uma ética burguesa que, por sua vez, possibilitou a construção dos meios que determinaram um desenvolvimento econômico sem precedentes, ainda que como um efeito colateral da ética protestante.

${ }^{4}$ Exercício prático que leva à efetiva realização da virtude, à plenitude da vida moral (FERREIRA, 1999).

${ }^{5}$ Obra póstuma originalmente publicada na Alemanha, em 1921

${ }^{6}$ Publicado originalmente em alemão em 1900. Neste mesmo ano, Simmel publicou em inglês A Chapter in the Philosophy of Value (Um capítulo na filosofia do valor), no qual discute como se dão os valores dos objetos. Numa crítica à concepção econômica da época, principalmente a Marx, para o qual o valor de mercado dos produtos era definido pelo tempo médio de trabalho empregado, Simmel afirma que são as trocas que estabelecem o valor de mercado: "The practically effective value is conferred upon the object, not merely by its own desirability, but by the desirability of another object (...). Hence the objects acquire a reciprocity of counterweight, which makes value appear in a quite special manner as an objective quality indwelling in themselves" (SIMMEL, 1900, p. 1).
} 
Essa discussão continua com Mannheim $(1962)^{7}$ - inspirado em Simmel e Weber - em $O$ homem e a sociedade; e, pela Escola de Frankfurt, ${ }^{8}$ principalmente por Horkheimer (2002), ${ }^{9}$ em Eclipse da razão, e Habermas (1994), ${ }^{10}$ com a publicação de Aspectos da racionalidade da ação. Profundamente influenciados por Weber - e no caso da Escola de Frankfurt, críticos a Marx -, esses autores se tornam críticos contumazes da sociedade moderna e do seu desenvolvimento em bases prioritariamente instrumentais para fins econômicos. Essa análise continua com inúmeros outros autores que combatem a racionalidade econômica como uma variação da racionalidade instrumental. Nesse sentido, torna-se importante a diferenciação entre economia substantiva e economia formal feita por Polanyi (1994), em El sustento del hombre, ampliando a discussão aristotélica, realizada em Política, entre economia e crematística.

A partir desta diferenciação, a crítica à racionalidade econômica será construída por meio de autores como Gorz (2003), ${ }^{11}$ em Metamorfoses do trabalho: crítica da razão econômica, e Illich (1976), ${ }^{12}$ em A convivencialidade. Estes dois textos são atualizações à crítica da racionalidade instrumental, como crítica à racionalidade econômica.

Isto posto, o objetivo neste artigo é resgatar a discussão weberiana seguida por outros autores (influenciados por Weber ou não), no sentido de captar a elucidação e a crítica à racionalização da sociedade 'moderna' e de suas bases essencialmente funcionais e instrumentais como um processo histórico. Valendo-se desta análise, é possível também compreender o conceito de racionalidade como chave, principalmente na sua tipologia instrumental, que contribui de forma fundamental para o exame da sociedade contemporânea e seus males. Não é objetivo, porém, construir uma crítica aos trabalhos desses autores, como o fez Ramos (1989), pelo fato de estes terem elucidado o processo de racionalização, evidenciando seus males sem propor alternativas teóricas e sociais. Considera-se que a elucidação da racionalização, evidenciando a sobreposição de uma razão funcionalinstrumental à razão de valor, seja a sua grande contribuição teórica e metodológica, capaz de explicar problemáticas tão atuais como a sócio-ambiental.

No entanto, acredita-se que a racionalidade instrumental em si não significa necessariamente efeitos negativos das ações humanas. A construção de meios com vistas a determinados fins, que denota a instrumentalidade da ação, não significa que o ganho esperado seja necessariamente individual e prejudicial ao coletivo, como frequientemente encontramos na literatura. Como esclarece Souto-Maior (1998), trata-se de um equívoco gerado pela associação da racionalidade instrumental com a racionalidade econômica, que, por sua vez, tem como premissa básica o interesse próprio e o egoísmo. Embora, essa afirmação de Souto-Maior seja bastante discutível no que se refere à racionalidade econômica, ela é inequívoca no que se refere à racionalidade instrumental. Conforme o autor: "a racionalidade instrumental exige apenas que a ação seja baseada no cálculo dos meios adequados para atingir os fins do indivíduo [ou do coletivo], sejam eles egoístas ou altruístas" (SOUTO-MAIOR, 1998, p. 971).

\section{A formalização da racionalidade material - Georg Simmel}

Simmel (1977) explica que, no período das trocas de mercadorias, ou seja, antes da existência do dinheiro, os objetos traziam em si sempre um sentido de privação, na medida em que eram percebidos como insubstituíveis em virtude de um valor de uso muito mais acentuado do que um valor de troca. Com a inserção do dinheiro como equivalente do valor dos objetos, houve uma formalização e uma desumanização das trocas, além de uma relativização do valor de uso dos objetos. Quanto mais passavam a ser percebidos como apenas objetos de

\footnotetext{
${ }^{7}$ Publicado originalmente em alemão em 1935.

${ }^{8}$ Escola de Frankfurt é o nome dado a um grupo de filósofos e cientistas sociais que se encontram no final dos anos de 1920. A Escola de Frankfurt se associa diretamente à chamada teoria crítica da sociedade e da indústria cultural.

${ }^{9}$ Publicado originalmente em 1955.

${ }^{10}$ A discussão de Habermas sobre a racionalidade é considerada uma das mais importantes sobre o tema. É feita em Aspectos da racionalidade da ação, publicado originalmente em 1977, que consta como um dos capítulos da obra Teoría de la acción comunicativa: complementos y estudios previos (1994). Contudo, mesmo sendo Habermas um crítico contumaz da sociedade moderna e da racionalidade instrumental, considera-se sua discussão sobre a racionalidade além do escopo deste trabalho.

${ }^{11}$ Publicado originalmente em francês, em 1988.

${ }^{12}$ Publicado originalmente em inglês, em 1973.
} 
troca, tanto mais perdiam seu valor de uso e mais se tornavam abstratos e passíveis de serem representados pelo dinheiro. Este se tornou a forma mais pura de interação, que, por sua vez, prescinde de seu próprio conteúdo. Logo, também a forma mais pura de impessoalidade e de desumanização das relações de troca, pela relativização do valor de uso dos objetos, na medida em que estas relações se tornavam formais. Mais tarde, o dinheiro, que inicialmente possuía um valor de referência em ouro ou prata, tornou-se puramente uma convenção representativa.

O problema, segundo Simmel (1977), é que o dinheiro foi transformado num fim. De uma convenção simbólica que representaria o valor dos objetos, ele acabou tornando-se o objeto. É como se a imagem refletida no espelho passasse a prescindir do real, do qual é reflexo. Ademais, no contexto da metrópole e do industrialismo, as relações se tornaram absolutamente objetivas e mediadas pelo dinheiro (formais). A objetivação não permaneceu somente entre empresas e empregados, entre fornecedores e empresas e entre essas e seus clientes, mas se estendeu para todos os campos da vida, tornando-se por fim o estilo de vida da sociedade moderna, essencialmente baseado em cálculos econômicos e, em seu extremo, em cálculos monetários. Além disso, a autonomia individual foi profundamente transformada pelo consumo em massa, que não permite mais a escolha individual do produto como ocorria antes (SIMMEL, 1903) -, esta questão será discutida na seção 7 deste artigo.

Simmel (1977) vê o dinheiro como símbolo da época moderna, que, por sua vez, é caracterizada pela impessoalidade dos relacionamentos humanos. Essas mudanças acompanham ou são acompanhadas pela transformação das faculdades intelectuais: o dinheiro como pura representação simbólica corresponde a uma maior capacidade de abstração intelectual em relação às fases anteriores. A consequiência mais grave desse processo é a 'transformação' dos valores qualitativos em valores quantitativos, já que a vida se torna um contínuo cálculo matemático baseado no valor dos objetos, representados pelo dinheiro, separando a atividade intelectual das atividades espirituais, especialmente no que se refere aos aspectos afetivos e emotivos.

O contexto perfeito para esta sociedade, cuja vida é totalmente racionalizada, continua Simmel (1903), é a cidade - a metrópole, na qual o homem se torna apenas uma pequena engrenagem de um grande sistema que ele mesmo sequer consegue compreender, mas do qual, no entanto, é forçado a participar, o que aumenta, cada vez mais, a sua atividade nervosa para adaptar-se às rápidas mudanças entre sensações internas e externas. Trata-se do predomínio do espírito objetivo, prático, instrumental, que suprime os aspectos mais substantivos e subjetivos, levando ao que Simmel chama de total alienação do indivíduo. A causa principal desta alienação, segundo ele, é a divisão do trabalho após a invenção da máquina, quando, então, o homem se torna parte de um processo de produção. Nesse sistema, segundo Simmel, o homem não se reconhece mais como autor do trabalho, numa inconsciência das próprias atividades. ${ }^{13}$ Quanto mais a racionalidade se desloca da consciência subjetiva e se instala em automatismos e suportes materiais (como o dinheiro e o próprio processo produtivo), tanto mais o indivíduo corre o risco de se esvaziar de suas prerrogativas, mediante a formalização das relações. A racionalidade tende a se tornar sem sentido, e os sentidos sem racionalidade. Ou seja, a formalização da racionalidade material, que é uma condição necessária para a racionalização dos processos produtivos, subverte as relações econômicas e de produção, assim como seu sentido e sua consciência.

\section{A razão moderna - Thomas Hobbes}

Como bem descreve Ramos (1989), o significado do termo 'razão' vem sendo construído e reformulado desde antes dos trabalhos de Hobbes e Bacon, quando era entendido como uma capacidade inerente à psique humana, que habilitava o indivíduo a distinguir entre o bem e o mal, entre o falso e o verdadeiro. Ou seja, numa acepção muito mais voltada para o que hoje é conhecido como categoria ética. ${ }^{14}$ Com Hobbes, a razão passa a ser compreendida como a capacidade racional que permite ao ser humano pensar (compreender) o mundo objetivo (empírico) e abstrato (transcendental) e o próprio pensamento. "A razão como uma capacidade que o indivíduo adquire "pelo esforço"” (RAMOS, 1989, p. 3, grifo do autor).

\footnotetext{
${ }^{13}$ Este tema foi abordado mais tarde por Mannheim e por Horkheimer - discussão que se apresentará ainda neste capítulo.

${ }^{14}$ Segundo Ramos (1989, p. 8), os principais representantes da Escola de Frankfurt "tentam restabelecer o papel da razão como categoria ética".
} 
A 'razão moderna' adquire significado de fruto do esforço, no sentido de aumentar a capacidade de utilização de critérios objetivos (meios e fins) e cálculo utilitário de consequiências. Para Hobbes, quando alguém raciocina, nada mais faz do que usar operações de adição e subtração para calcular as consequiências de um determinado ato:

Razão, nesse sentido, nada mais é do que cálculo (isto é, adição e subtração) das conseqüencias de nomes gerais estabelecidos para marcar e significar nossos pensamentos. Digo marcar quando calculamos para nós próprios, e significar quando demonstramos ou aprovamos nossos cálculos para os outros homens .(HOBBES, 2000, p. 51, grito do autor)

Isto é, um ato racional, tal como propõe Hobbes, é precedido de uma escolha que calcula a melhor opção diante de determinada situação. É esta 'equação' desvelada por Hobbes que se torna a base do conceito de racionalidade referente a fins (de escolha racional de meios e fins ou racionalidade formal ou ainda funcional), conforme a proposição de Weber.

\section{A racionalidade formal - Max Weber}

A racionalidade instrumental (referente a fins), como a entende Weber, não se limita ao campo meramente econômico, mas está presente em todo o processo civilizatório ocidental, também nos campos político e social, cultural e religioso. Ou seja, é associada a um sistema econômico, social, cultural e religioso. Ela é imanente ao desenvolvimento ocidental e à sua estrutura, contemplando aspectos técnicos (científicos), administrativos e burocráticos. De acordo com Weber, o capitalismo ocidental, na sua forma moderna, foi fortemente influenciado pelo desenvolvimento das possibilidades técnicas, e a sua racionalidade decorre de maneira direta da "calculabilidade precisa de seus fatores técnicos mais importantes" (Weber, 1996, p. 9). Implica dizer, portanto, que o seu desenvolvimento dependeu, em grande parte, do igual desenvolvimento da ciência ocidental, impulsionando e sendo impulsionado por ela. Nessa interpretação, o capitalismo é um dos fatores de maior significação na constituição do desenvolvimento ocidental, no âmbito da concepção de cálculo de meios e fins, porque ocorre da forma mais racionalizada possível.

De fato, em A ética Protestante e o Espírito do Capitalismo, Weber deixa claro que a busca do lucro no capitalismo é algo permanente e racional, enquanto a simples 'ânsia do lucro' é qualificada como irracional. O 'impulso para o ganho' sempre esteve presente na história humana em todas as épocas, em toda espécie de pessoas e condições sociais, em todos os países da terra e não tem nada a ver com o capitalismo em si. "O desejo de ganho ilimitado não se identifica nem um pouco com o capitalismo [ocidental], e muito menos com o 'espírito do capitalismo'", ainda que o capitalismo equivalha à procura do lucro sempre renovado (WEBER, 1996, p. 4). O desejo de ganho sempre existiu onde e quando existiram trocas. A ânsia pelo lucro é uma espécie de condição da pessoa, enquanto a 'ação econômica capitalista' é assentada no trabalho livre, no desenvolvimento de possibilidades técnicas e cálculos precisos quanto a possibilidades de ganho. Esta 'ação econômica capitalista', tal como Weber a denomina, é aquela baseada "na expectativa de lucro através da utilização das oportunidades de troca" (WEBER, 1996, p. 4) que equivalem a oportunidades formais de lucro ${ }^{15}$ e ao desenvolvimento dos meios que permitem atingir os fins a partir de cálculos precisos, ou seja, a racionalidade instrumental.

O capitalismo é resultado, ainda, de uma moderna organização racional viabilizada, sobretudo, pela separação entre empresa e economia doméstica e pela criação da contabilidade racional, associadas ao desenvolvimento das possibilidades técnicas.

Sua racionalidade decorre [...] de maneira direta da calculabilidade precisa de seus fatores técnicos mais importantes. Implica isso principalmente numa dependência da ciência ocidental, notadamente das ciências matemáticas e das experimentalmente exatas ciências da natureza. (WEBER, 1996, p. 910)

\footnotetext{
${ }^{15}$ Princípio a partir do qual, segundo Polanyi (2000), derivou o sistema de mercado auto-regulável.
} 


\section{A ética protestante e a racionalização da vida}

Weber inicia sua análise da ética protestante pelas 'sentenças morais e de virtude' (discurso) de Benjamin Franklin $^{16}$, que, como Weber mesmo previne, não se trata de uma simples técnica de vida ou de bom senso comercial, mas de uma ética peculiar, um ethos com qualidades e atitudes morais "coloridas pelo utilitarismo". "A honestidade é útil porque assegura o crédito; do mesmo modo a pontualidade, a laboriosidade, a frugalidade, e esta é a razão pela qual são virtudes" (WEBER, 1996, p. 32). Ou seja, nestas 'sentenças', assim como na ética calvinista, está a fundamentação de todo um código centrado na moralidade e na racionalização metódica da conduta neste mundo e que se baseia em obras construídas para a garantia da salvação em outro mundo. ${ }^{17}$ Isto é, o trabalho como uma vocação e 'lugar' da prática das virtudes presentes no puritanismo, principalmente calvinista, e que são determinadas pela doutrina da predestinação. ${ }^{18}$

A vida neste mundo dirigida para uma única finalidade, a salvação eterna, é completamente racionalizada para a finalidade de aumentar a glória de Deus. "O processo de santificação da vida podia, assim, tomar quase o caráter de uma empresa comercial” (WEBER, 1996, p. 87). Há uma completa instrumentalização da vida com o objetivo de salvação - a cristianização da vida -, consequiência de um tipo de conduta ética altamente metódica, imposta pelo calvinismo. A fonte do caráter utilitário da ética calvinista, e da sua concepção de vocação, encontra-se, portanto, no objetivo de salvação e na conseqüente racionalização ${ }^{19}$ da vida.

Esta ascese do trabalho para a glória de Deus, como denomina Weber, é encarada com absoluta seriedade pelos puritanos, tanto na Europa como nos Estados Unidos, principalmente no norte. É vista como um mandamento de Deus a todos, segundo o qual a perda de tempo é o primeiro e o principal pecado. Por um lado, tem um sentido de ir contra qualquer atitude de desfrutar espontaneamente a vida, eliminando, assim, todo tipo de atividade lúdica não planejada e não pensada para a glória de Deus. De outro, a afirmação de que o trabalho não é um trabalho qualquer, mas uma atividade racional, uma vocação pedida por Deus e "orientada primeiramente por critérios morais e depois pela escala dos bens produzidos. [...] A ênfase do significado ascético de uma vocação fixa propiciou [ainda] uma justificação ética para a moderna divisão do trabalho" (WEBER, 1996, p. 116-117).

Além disso, o uso dos bens e o conceito de propriedade são totalmente submetidos ao 'projeto de Deus' para o homem:

O homem é apenas um guardião dos bens que lhe foram confiados pela graça de Deus. Como servo da Bíblia, deve prestar conta até o último centavo, não lhe sendo, pois, nem um pouco imaginável gastar o que quer que fosse sem uma finalidade que não a glória de Deus, mas apenas a sua própria satisfação. (WEBER 1996, p. 122)

\footnotetext{
${ }^{16}$ Benjamin Franklin (nasceu em Boston em 1706 e morreu na Filadélfia em 1790) foi jornalista, editor, autor, filantropo, abolicionista, funcionário público, cientista, diplomata e inventor americano - e também, um dos líderes da Revolução Americana. Muito conhecido por várias de suas citações e pelas experiências com a eletricidade. Um homem religioso (calvinista) e, ao mesmo tempo, uma figura representativa do lluminismo. Trocava correspondência com membros da sociedade lunar e foi eleito membro da Royal Society. Em 1771, Franklin tornou-se o primeiro Postmaster General (ministro dos correios) dos Estados Unidos da América (WIKIPÉDIA).

17 "O mundo existe para a glorificação de Deus, e somente para este fim. O cristão eleito está no mundo apenas para aumentar esta glória, cumprindo seus mandamentos ao máximo de suas possibilidades. Mas Deus requer obras sociais de cristão, porque Ele deseja que a vida social seja organizada segundo seus mandamentos, de acordo com aquela finalidade. A atividade social do cristão no mundo é primeiramente uma atividade in majorem gloriam Dei [para a maior glória de Deus]. Este caráter é assim partilhado pelo labor especializado em vocações, justificado em termos de "amor ao próximo"' (WEBER, 1996, p. 75). Este "amor ao próximo" devia ser praticado na normalidade do cumprimento das tarefas diárias e também só podia ser praticado para a glória de Deus.

${ }^{18}$ A doutrina da predestinação, enfatizada principalmente no calvinismo, pode ser exposta sem maior rigor, mais ou menos na seguinte equação: o crente já nasce predestinado a ser salvo para a vida eterna ou a ser condenado à morte eterna. A questão é: "Sou um dos eleitos? E como posso estar seguro deste estado de graça?" O resultado desta equação é que o crente deve ter fé na sua salvação, ou seja, produzem-se, em vez de fieis humildes que confiam na graça de Deus, fiéis autoconfiantes que buscam alcançar, como meio mais adequado, a sua autoconfiança numa intensa atividade profissional, afugentando as dúvidas e dando certeza da graça. "Assim, apesar da inutilidade das boas obras como meio de obtenção da salvação [...] elas eram indispensáveis como sinal de escolha. Eram os meios técnicos não de compra da salvação, mas de libertação do medo da condenação" (WEBER, 1996, p. 80).

${ }^{19}$ Esta racionalização, segundo Weber (1996), eliminou por completo a mágica como meio de salvação, assim como as questões acerca do significado do mundo e da vida, numa completa ausência de senso crítico e de conflitos éticos, embora não se tenha eliminado do indivíduo a sua autonomia.
} 
Essa restrição ao consumo, combinada com trabalho metódico e com liberdade para produzir riqueza, levou ao resultado que Weber considera óbvio: a acumulação capitalista. Em vez de ser gasto em bens de consumo, o capital passou a ser aplicado sistematicamente no que, em Marx, é definido como 'meios de produção', resultando conseqüentemente no desenvolvimento sem precedentes do capitalismo. Evidentemente, como Weber mesmo conclui, essas práticas levaram a uma inversão que, inevitavelmente, resultou na redução da religiosidade, fazendo surgir em seu lugar uma ética profissional especificamente burguesa, dominada pela produção de dinheiro como a finalidade última da vida. Aflorou, assim, a 'racionalidade econômica' que, superando a simples satisfação das necessidades, levava à produção cada vez maior de excedentes econômicos, os quais, por sua vez se multiplicaram.

Entretanto, ainda segundo Weber, não foi a existência de excedentes que impulsionou de forma decisiva o processo revolucionário de desenvolvimento do capitalismo, mas precisamente o surgimento de um novo espírito.

A questão das forças motivadoras da expansão do capitalismo moderno não é, em primeira instância, uma questão de origem de somas de capital disponíveis para uso capitalístico, mas principalmente, do desenvolvimento do espírito do capitalismo. Onde ele aparece e é capaz de se desenvolver, ele produz seu próprio capital e seu suprimento monetário como meios para seus fins e não o inverso (WEBER 1996, p. 44).

Em outras palavras, o acúmulo de capital é apenas uma conseqüência, um efeito colateral da ascese puritana que produziu uma ética profissional, tanto do empreendedor burguês, com a sua correção formal e conduta ética, como do trabalhador sóbrio e 'industrioso'. Nessa ética, o trabalho é, para ambos, uma finalidade de vida desejada por Deus. Nas palavras de Weber (1996, p. 131), esta ascese influenciou enormemente na definição da moralidade, determinando e contribuindo "poderosamente para a formação da moderna ordem econômica e técnica, ligada à produção em série através da máquina, [...] [bem como, o próprio estilo de vida nascido sob esse sistema] e quem sabe, o determinará até que a última tonelada de combustível tiver sido gasta" . O ascetismo e o utilitarismo puritano racionalizaram e remodelaram o mundo, como nunca antes na História, segundo Weber (1996). A racionalidade econômica, que, segundo Gorz (2003), havia sido 'contida' por longo tempo não apenas pela tradição, mas também por outros tipos de racionalidade, encontra agora campo fértil com a transformação da ascese protestante em ascese burguesa. "O capitalismo industrial só pôde desenvolverse a partir do momento em que a racionalidade econômica emancipou-se de todos os outros princípios de racionalidade, para submetê-los a seu único domínio" (GORZ, 2003, p. 27).

\section{A racionalidade funcional - Karl Mannheim}

Influenciado por Georg Simmel e Max Weber, Karl Mannheim concebe a racionalidade instrumental como uma racionalidade prática e funcional. Ou seja, o termo 'racional' deixa de ser simplesmente o ato de pensar, para tornar-se a realização de "medidas organizadas de forma a levar a um objetivo previamente definido, recebendo todos os elementos dessa série de atos uma posição e um papel funcionais" (MANNHEIM, 1962, p. 63). Para este autor, a funcionalidade da racionalidade instrumental está nos meios e não nos fins:

É possível lutar para atingir um objetivo escatológico irracional, como a salvação, organizando-se o comportamento ascético de tal modo que ele leve a esse objetivo ou, de qualquer modo, a um estado de êxtase irracional. Não obstante, devemos dar a isso o nome de comportamento racional porque está organizado, pois cada ato tem um papel funcional na consecução do objetivo final. (MANNHEIM, 1962, p. 63)

Portanto, a funcionalidade é a característica que indica quais os meios mais eficientes para atingir o objetivo. A finalidade não precisa ser necessariamente racional em si. Aliás, como se verá mais adiante em Horkheimer, uma das características da racionalidade instrumental instituída na sociedade moderna é justamente a de não questionar ou refletir sobre os fins. No mundo moderno, os homens gastam as suas vidas produzindo coisas sem questionar a finalidade do que estão produzindo ou os efeitos de sua utilização. 
Nesse sentido, para Mannheim, a funcionalidade de uma racionalidade pode ser determinada por dois critérios: a organização em função do objetivo; e a conseqüente calculabilidade, considerada do ponto de vista de quem procura se ajustar a ela. A funcionalidade dos atos independe da consciência do objetivo final das ações realizadas. Um soldado realiza, muitas vezes, seus atos funcionalmente racionais sem, no entanto, ter uma idéia do objetivo final de suas ações ou do papel funcional de cada ato dentro do todo. O mesmo ocorre com os membros das sociedades industriais que trabalham em cargos administrativos ou em postos da cadeia de produção. Conhecem e racionalizam muito bem as suas funções, mas nem sempre têm consciência do papel funcional que exercem dentro do todo. Esse 'todo' é organizado, conforme Mannheim, com referência a um objetivo definido, e o indivíduo ajusta-se a ele, calculando as próprias ações.

Seguindo essa lógica, Mannheim afirma que:

Enquanto o indivíduo nas sociedades antigas, apenas ocasionalmente e em esferas limitadas, agia de uma maneira funcionalmente racional, na sociedade contemporânea ele é obrigado a agir dessa forma em um número de esferas de vida cada vez maior. [...] A preocupação com a carreira exige um máximo de autodomínio, pois envolve não só os processos práticos de trabalho, mas também a regulamentação prescritiva tanto de idéias como de sentimentos que é permitido ter, e ainda do tempo de lazer de cada pessoa. (MANNHEIM, 1962, p. 65-66)

Isso ocorre em função da crescente complexidade da organização da sociedade e da divisão do trabalho, levando ao que Mannheim denomina auto-racionalização, que é o controle sistemático, pelo indivíduo, de seus impulsos, em função da funcionalidade da organização da qual faz parte. Ou a subordinação ou anulação dos seus motivos internos - crenças, convicções morais e éticas - a uma finalidade externa no sentido de cumprir o seu papel como peça funcional de uma engrenagem e conseqüentemente 'ganhar a vida', sustentar a família e assim por diante. Ou seja, "a racionalização funcional de atividades objetivas, em última análise, leva à autoracionalização" (MANNHEIM, 1962, p. 66).

Entretanto, para Mannheim, a auto-racionalização não é ainda a forma mais radical de racionalização do agente, mas, sim, a auto-observação, que supera o simples treinamento mental contido na auto-racionalização e significa uma autotransformação. É a auto-reflexão, com o objetivo de remodelar-se ou transformar-se, que funciona como uma 'consciência da própria situação'. Nesse sentido, os puritanos, por exemplo, passaram, primeiro, pelo processo de auto-racionalização, controlando seus impulsos e subordinando todos os aspectos mágicos e transcendentais em função de uma racionalização e secularização da própria vida. E, depois, pelo processo de auto-observação ou autotransformação, a partir do qual nascia a própria burguesia capitalista.

A fonte dessa racionalização é determinada e vem da industrialização, como forma específica de organização social. A industrialização implica a racionalidade funcional, que é a organização dos membros da sociedade em função de finalidades objetivas. A racionalização industrial aperfeiçoou a racionalidade funcional, mas ao mesmo tempo provocou proporcional diminuição da capacidade de julgamento independente dos indivíduos, o que significa - na interpretação de Ramos (1989) - que o desenvolvimento técnico e econômico pode corresponder a um baixo desenvolvimento ético e moral. ${ }^{20}$ De acordo com Ramos, isso não significa que a racionalidade funcional deva ser abolida, mas que a sua predominância em detrimento de valores mais substantivos tira dos indivíduos a capacidade de escolhas éticas e morais, levando ao que Mannheim denominou como 'desenvolvimento desproporcional' das faculdades humanas. Ou seja, o desequilíbrio entre o desenvolvimento técnico e o da capacidade moral e de controle social que diz respeito a ele. "[...] os seres humanos podem fazer usos dos mais modernos produtos do gênio inventivo para satisfazer impulsos e motivos primitivos" (MANNHEIM, 1962, p. 52). Com essa afirmação, Mannheim prevê um colapso social se não for alcançada a simetria entre o controle social racional, o domínio individual de seus impulsos e o desenvolvimento tecnológico. Isso porque se tornou evidente na sua época e, mais ainda hoje, a desproporção com que avançou o conhecimento técnico em relação à capacidade moral e o discernimento quanto ao seu uso. A guerra e a destruição da natureza, assim como a própria degradação social em todos os sentidos - moral, econômica e ética - são bons exemplos.

\footnotetext{
${ }^{20}$ Nesse mesmo sentido, Horkheimer (2002) afirma que a democracia destituída do seu fundamento racional torna-se exclusivamente dependente dos chamados interesses do povo, e estes são funções das forças cegas da economia.
} 
É como se, ao longo da História, o homem tivesse se empenhado muito em transformar o mundo e construir o desenvolvimento sem, no entanto, pensar sobre o que estava construindo. O que faltou foi pensar e refletir sobre o significado e as consequiências desse desenvolvimento. E, nesse sentido, a tecnologia e todo o desenvolvimento da ciência tornam-se um remédio sem a bula moral e ética que regule o seu uso e previna seus efeitos colaterais.

\section{A racionalidade subjetiva - Max Horkheimer}

O conceito de racionalidade em Horkheimer, tal como em Weber e Mannheim, é teleológico e se divide em duas categorias: a racionalidade 'funcional' ou 'instrumental' como racionalidade 'subjetiva', e a racionalidade 'substancial' como racionalidade 'objetiva'. Para Horkheimer (2002), os aspectos subjetivos (instrumental) e objetivos (substancial) da razão sempre estiveram historicamente presentes e "a predominância do primeiro sobre o último se realizou no decorrer de um longo processo", levando à crise atual da razão, que se deve à incapacidade de conceber o aspecto objetivo (substancial) ou a sua negação como sendo uma ilusão. "Na medida em que é subjetivada, a razão se torna também formalizada"21 (HORKHEIMER, 2002, p. 16-17).

Conforme Horkheimer, quando se concebeu a idéia de razão, o objetivo maior era que fosse um instrumento para compreender, pensar os fins, no sentido de 'determiná-los'. A razão como uma capacidade não só de construir os meios para atingir determinados fins, mas também para julgar ética e moralmente os fins -, a razão como uma capacidade de reflexão. Horkheimer afirma que foi por refletir e questionar a racionalidade subjetiva e formalista (instrumental), advogada pelos sofistas, que Sócrates foi morto. "Sócrates sustentava que a razão concebida como compreensão universal, devia determinar as crenças e regular as relações entre os homens, e entre o homem e a natureza" (HORKHEIMER, 2002, p. 20).

Entretanto, com o passar do tempo, a razão foi se tornando cada vez mais subjetiva (formal, funcional, ou instrumental). Contribuiu para isso, conforme Horkheimer (2002), o divórcio entre razão e religião, que teve como marca o enfraquecimento do aspecto objetivo (substancial) da razão e, conseqüentemente, provocou um aumento em sua formalização. Esta separação não se deu sem conflitos e, embora posteriormente as duas tenham sido consideradas como ramos separados da cultura, seus conteúdos foram profundamente afetados, principalmente o relativo à razão, em virtude de um efeito contrário da ação dos filósofos iluministas: "Os filósofos do Iluminismo atacaram a religião em nome da razão; e afinal o que eles mataram não foi a Igreja, mas a metafísica e o próprio conceito de razão objetiva [substancial], a fonte de poder de todos os seus esforços"(HORKHEIMER, 2002, p. 26).

Mais tarde, tendo passado pelos inúmeros processos filosóficos, históricos e sociais, tais como a força do positivismo e do pragmatismo e o domínio político e econômico do liberalismo, a razão 'cede' sua autonomia, tornando-se definitivamente um instrumento. Sob essas correntes, enfatiza-se cada vez mais o seu aspecto instrumental, pondo de lado qualquer referência a um conteúdo objetivo (substancial). "A razão tornou-se algo inteiramente aproveitado no processo social. Seu valor operacional, seu papel no domínio dos homens e da natureza tornou-se o único critério para avaliá-la" (HORKHEIMER, 2002, p. 29). Ou seja, é racional se for funcional e não se for pensado ou pensável:

É como se o próprio pensamento tivesse sido reduzido ao nível do processo industrial, submetido a um programa estrito, em suma, tivesse se tornado parte de e uma parcela da produção [...]. Quanto mais as idéias se tornam automáticas, instrumentalizadas, menos alguém vê nelas pensamentos com um significado próprio (HORKHEIMER, 2002, p. 30).

É como se a diferença entre pensamento e ação fosse completamente anulada, tornando, assim, todo pensamento um ato. Não um ato pensado, com origem na razão substantiva, mas um ato automático, formalizado, funcional no contexto da vida racionalizada, mas não pensada.

\footnotetext{
${ }^{21}$ Horkheimer usa os termos 'subjetivação' e 'formalização' como equivalentes no trato da distinção da racionalidade. A racionalidade subjetiva equivale ainda à racionalidade instrumental, enquanto a racionalidade objetiva equivale à racionalidade substantiva.
} 
Esta concepção de razão, na qual sobra mecanização e falta reflexão, foi essencial para o desenvolvimento da indústria e do próprio capitalismo. Do contrário, como explicar que durante tanto tempo o desenvolvimento capitalista tenha destruído sistematicamente a natureza sem que se tenha produzido qualquer tipo de reflexão mais séria nesse sentido, a não ser por apenas uns poucos que, tendo 'perdido a razão', ousaram questionar o desenvolvimento e a vida moderna, como o fez Thoreau ? $^{22}$ Somente por uma quase absoluta falta de reflexão no sentido de pensar e refletir sobre os fins para os quais o 'desenvolvimento' estava sendo construído poderia ter permitido uma noção de desenvolvimento tão fundamentada no crescimento econômico. Destituído do seu fundamento racional substantivo que, em última instância, é a reflexão acerca dos fins para os quais se constroem os meios e dos seus significados em si, o desenvolvimento se deu quase que exclusivamente segundo as bases utilitárias das forças econômicas. Isto é, segundo uma lógica, com base na qual só é racional quando serve a algum propósito, o que retira o valor intrínseco das ações e das suas finalidades. Nessa lógica, segundo Horkheimer, uma atividade física ao ar livre, por exemplo, só é concebível se servir a algum propósito, como o de melhorar a saúde. Do contrário, nada mais é do que perda de tempo, porque foi destituída do seu valor em si. Ver a paisagem, sentir o ar fresco, comungar com a natureza tornam-se ações sem significado, segundo a lógica utilitarista.

Acompanhando o raciocínio de Horkheimer, poder-se-ia especular sobre várias outras atividades que, no atual estágio de desenvolvimento, foram destituídas dos seus valores intrínsecos e reduzidas apenas ao seu valor utilitário. Entretanto, aqui, se especulará apenas sobre uma - tema principal deste trabalho -, a conservação ambiental. Nesse sentido, a questão que se apresenta é: em nossa sociedade e principalmente nos setores industriais, onde decisivamente predomina a racionalidade instrumental e econômica, a conservação ambiental é um valor em si? Toda a discussão que se instaurou em torno dessa problemática se deve ao reconhecimento do meio ambiente como um valor intrínseco a esta sociedade ou, exclusivamente, ao seu valor utilitário para o atual processo de desenvolvimento?

O que Horkheimer e os demais autores até aqui trabalhados teriam a dizer sobre essa questão é que os problemas sócio-ambientais são resultados de um processo histórico, no qual a sociedade se desenvolveu quase que exclusivamente calcada em bases instrumentais, destituída e prescindindo da razão substantiva. Ou seja, pensou-se o processo de desenvolvimento quase que exclusivamente como crescimento econômico, privado dos seus valores intrínsecos. "A única consideração que poderia detê-los [os grupos econômicos] seria a possibilidade de que os seus próprios interesses estivessem em risco, sem ter nada a ver com a violação da verdade ou da razão" (HORKHEIMER, 2002, p. 37).

Nessa citação, Horkheimer evidentemente não se refere à problemática sócio-ambiental. À sua época, ela ainda não tinha aflorado tal como a entendemos hoje: como resultado da sobreposição dos subsistemas social e econômico sobre os demais subsistemas que compõem a biosfera. Alude o autor à democracia, defendida pelos agentes econômicos não porque estes a tivessem como uma verdade ou por seus fundamentos filosóficos e qualidades morais, mas porque, em determinados contextos, ela é altamente útil, como poderia sê-lo a própria ditadura. Contudo, numa associação lógica ao pensamento de Horkheimer, é possível referir-se à conservação ambiental no contexto atual do desenvolvimento, que é pensado quase que exclusivamente do ponto de vista da economia e em relação aos seus efeitos nocivos, percebidos pelos agentes econômicos somente quando estão em jogo seus interesses diretos. Ou seja, a preocupação com a conservação só é considerada quando significa, de alguma forma, uma ameaça às possibilidades de ganho.

Todavia, Horkheimer não deixou de perceber que a natureza era afetada pela racionalização formal-subjetiva e, portanto, pela gênese da sobreposição do economicismo sobre os demais sistemas, que é a razão formalizada, o espírito do capitalismo e, conseqüentemente, do industrialismo. Segundo ele, sob o jugo desta razão, a natureza é compreendida como uma mixórdia (caos), na medida em que não corresponde ao uso humano, isto é, quando não é possível transformá-la de imediato em meio ou instrumento para determinado fím. Na era da razão

\footnotetext{
${ }^{22}$ Henry David Thoreau publicou, em 1854, Walden, ou $A$ vida nos bosques, em que descreve sua experiência de dois anos, solitário, sobrevivendo apenas do trabalho natural. Um livro de descrições exatas e, mesmo assim, poéticas. Tornou-se um clássico da literatura estadunidense como sendo um livro de proporções místicas. E também considerado uma grande crítica à sociedade moderna e a tudo 0 que tirava a liberdade do homem e o degradava. Além de Walden, escreveu outra obra de grande expressão e repercussão, Desobediência civil, que inspirou Gandhi.
} 
formalizada, a natureza foi despojada do seu valor ou significado intrínseco, da mesma forma que o homem foi despojado de todos os seus instintos, exceto o de autoconservação. As formas deste despojamento são as mais variadas. Pode ocorrer com a simples associação de campos, como sinônimo de boa caçada, feita pelos antigos caçadores, ou uma paisagem bonita como oportunidade de propaganda de cigarros, efetuada pelos homens de negócios modernos, até a completa transformação da natureza em meio racionalizável a serviço da industrialização, cujos fins são os mais diversos.

\section{A economia em dois sentidos}

"A natureza é hoje mais do que nunca concebida como um simples instrumento do homem. É objeto de uma total exploração, que não tem objetivo estabelecido pela razão e, portanto, não tem limite" (HORKHEIMER, 2002, p. 112). Esta falta de limites em relação à natureza, apontada por Horkheimer, tem suas raízes ainda no tempo de Aristóteles (séc. IV a.C.), que, através da distinção entre economia e crematística, em Política, denuncia a falsidade da formulação (versículo) de Sólon, ${ }^{23}$ segundo a qual "não foi fixado para o homem um limite de riquezas" (ARISTÓTELES, 1988, p. 25). Segundo Lisboa (2000):

Nas origens do pensamento ocidental [...], Aristóteles [...] construiu a palavra "Economia", (administrar a casa, em grego - e este é o sentido etimológico original) - dando a ela o significado de forma natural da arte de aquisição - através da diferenciação da palavra "Crematística" - a forma artificial ou mercantil de adquirir bens. (LISBOA, 2000, p. 19, grifo do autor)

Aristóteles (1988, p. 24) faz uma diferenciação entre a economia doméstica (baseada nos meios para a satisfação das necessidades) - a qual denomina simplesmente de economia, e que constitui "os meios de obter os alimentos estritamente necessários [que] são evidentemente um dom que a natureza concede a todos os seres [...]" - e a crematística, que é a forma de aquisição de bens. Esta aquisição não se dá com o objetivo de suprir apenas necessidades, tal como Aristóteles entende ser a economia, mas como acúmulo além das necessidades, cuja finalidade é a de enriquecer. A primeira é apenas uma maneira de obter os alimentos necessários à vida, que são fornecidos gratuitamente pela natureza em quantidade necessária, enquanto a segunda pertence à arte de enriquecer, em que o 'homem quer acumular sem fim e sem medida'.

Existe, portanto, segundo Aristóteles, dois gêneros de arte da aquisição: "uma espécie de arte da aquisição que é por natureza uma parte da economia doméstica", e outra chamada de arte de enriquecer, cuja "noção [é] de que não há limites para as riquezas. [...]. Uma delas é natural e a outra não é" (ARISTÓTELES, 1988, p. $24-$ 25). Uma é a aquisição natural ou 'economia' e a outra é a aquisição artificial ou 'crematística'. A primeira diz respeito ao valor de uso e às necessidades para as quais adquirimos os bens. A segunda guarda relação com o valor de troca no sentido mercantil, com vistas à acumulação e ao lucro.

Nas palavras de Aristóteles, é dessa noção de lucro que veio a idéia de riqueza:

Emergiu a idéia de que a arte de enriquecer está especialmente vinculada ao dinheiro, e que sua função é descobrir as fontes capazes de proporcionar um suprimento maior de produtos, no pressuposto de que esta arte cria riquezas e posses; efetivamente, presume-se que a riqueza consiste em grande quantidade de dinheiro, pois é com o dinheiro que se fazem negócios e o comércio. (ARISTÓTELES, 1988, p. 26)

Essa desmaterialização da riqueza, ${ }^{24}$ a partir do uso do dinheiro, tem como base, segundo Aristóteles, o desejo de enriquecimento ilimitado:

A causa deste estado de espírito é o fato de a intenção destas pessoas ser apenas viver, e não viver bem; da mesma forma que o desejo de viver é ilimitado, elas querem que os meios de satisfazê-lo também sejam ilimitados. [...]. Tais pessoas, porém, transformam todas estas faculdades em meios de

\footnotetext{
23 "Legislador e poeta, arconte em Atenas em 594/593 a.C.; o fragmento citado constitui o №. 13, verso 71, na coletânea de Bergk, Poetae Lyrici Graeci (página 46, do volume II, 4ª . edição, Leipzig, 1882)" (ARISTÓTELES, 1988, p. 288 - nota no 22).

${ }^{24}$ A desmaterialização da riqueza é tratada por Simmel (1977), por Polanyi (1994) e por Marx (2000).
} 
proporcionar riqueza, na convicção de que a riqueza é o fim a atingir e que tudo mais deve contribuir para a consecução deste fim. (ARISTÓTELES, 1988, p. 27)

A diferenciação feita por Aristóteles entre economia (economia com a finalidade de suprir as necessidades) e crematística (economia com a finalidade de lucro) demonstra, portanto, a gênese da inversão - de 'meio' para 'fim' -, ou seja, de meio para satisfazer as necessidades, a economia transforma-se em finalidade da vida humana. Nesse processo histórico de transformação, a finalidade primeira que designava o termo 'economia' (segundo o sentido dado por Aristóteles) foi perdendo espaço, e o termo passou a ser reconhecido cada vez mais como o que designa a economia no seu sentido formal (da crematística).

Karl Polanyi (1994), seguindo o caminho aberto por Aristóteles, tem a preocupação de esclarecer o 'lugar da economia' na sociedade e criticar, apontando como um equívoco, a unificação dos dois sentidos de economia num único termo, porque se ignoram as duas raízes distintas e independentes e, assim, os seus dois significados:

Tem raízes distintas, e são independentes um do outro. [...]. O primeiro significado, o formal, surge do caráter lógico da relação meios-fins como quando usamos <<economizar〉> (no sentido de poupar) o econômico (barato), a partir do qual surge a definição do termo econômico em termos de escassez. $O$ segundo significado, o substantivo, assinala o fato elementar de que os seres humanos, (como qualquer outro ser vivente), não podem subsistir sem um entorno físico que os sustente; esta é a origem da definição substantiva do econômico. (POLANYI, 1994, p. 91, grifo do autor)

De acordo com Polanyi (1994), o significado substantivo está relacionado à dependência dos seres humanos tanto da natureza como dos seus semelhantes, no sentido da busca pelo sustento, na medida em que o ser humano sobrevive a partir da interação com outros seres humanos e com o meio ambiente natural. A economia substantiva comporta dois níveis inseparáveis: "a interação entre o homem e seu entorno [meio ambiente] e a institucionalização do processo" (p. 104), através do qual se buscam os meios para satisfazer as necessidades materiais, em que "o material são os meios e não as necessidades" (POLANYI, 1994, p. 92).

O significado formal, por sua vez, afirma Polanyi, tem origem completamente diferente, porque não parte da busca dos meios para suprir as necessidades humanas, mas de uma relação puramente formal, de lógica matemática e desumanizada, entre meios e fins, em que o objetivo é "obter o máximo resultado dos próprios meios" (POLANYI, 1994, p. 92). Está impresso nessa afirmação, segundo Polanyi, o sentido de maximizar, popularmente conhecido como economizar.

Polanyi considera que a fusão destes dois conceitos põe em prática o que denomina de falácia ${ }^{25}$ econômica, "que consiste na tendência a identificar a economia humana com a sua forma de mercado" (POLANYI, 1994, p. 93), ou seja, contemplando apenas a definição de escassez, enquanto o aspecto substantivo é excluído. Houve, portanto, um processo de monopolização, em termos semânticos, do termo econômico no sentido de escassez, quando se fez a fusão, num mesmo conceito, desta noção com a da satisfação das necessidades materiais. O significado do termo econômico apenas baseado na escassez só é justificável e racional onde a economia de mercado, na qual não há limites para a riqueza, prevalece como sistema econômico. Entretanto, a exemplo do que faz Aristóteles quando desvenda a falsidade do versículo de Sólon, Polanyi reafirma que a verdadeira riqueza são as coisas necessárias e não as excedentes:

As verdadeiras riquezas de uma família e de um Estado são as coisas necessárias para a vida que podem ser alcançadas e conservadas e as quais só são meios para um fim, e como todos os meios estão intrinsecamente limitados e determinados pelos seus fins. Na casa são meios de vida; na polis são meios para a boa vida. Os desejos e necessidades humanas, portanto, não são ilimitados (POLANYI, 1994, 102).

Conforme interpreta Lisboa (2000, p. 2), Polanyi "nega que o sustento da humanidade suponha um problema de escassez". Além disso, pelo fato de que na sociedade de mercado o objetivo passou a ser predominantemente

\footnotetext{
25 "Falácia é uma armadilha enganosa resultante de um erro lógico" (LISBOA, 2000, p. 2).
} 
o acúmulo de ganhos monetários, tornou-se difícil conceber qualquer outra forma de economia que não seja baseada nesse princípio (LISBOA, 2000). Entretanto, em virtude do rol de consequiências geradas pelo desenvolvimento da economia apenas baseada no seu sentido formal, torna-se cada vez mais urgente desfazer o equívoco, não só semântico, mas também prático, restabelecendo o 'lugar da economia' na sociedade como uma dimensão com a finalidade de busca do sustento humano. Ou seja, desfazer a inversão de que a economia no seu sentido formal é um fim, para voltar-se ao seu significado substantivo, como um meio.

\section{A racionalidade econômica}

Em Economia e sociedade, Max Weber demonstra, através dos conceitos de 'gestão econômica' e 'ação economicamente orientada', que, além da formalização da racionalidade material (a busca dos meios de sobrevivência), a racionalidade econômica é também a instrumentalização de toda a vida em função de finalidades econômicas.

O conceito de 'gestão econômica' de Weber "significa [...] uma orientação subjetiva primariamente econômica. (Subjetiva porque o que importa é a crença na necessidade da provisão, e não a necessidade objetiva desta [provisão])" (WEBER, 1999, p. 38, grifo do autor). Dito de outro modo, ela tem um caráter mais administrativo, de forma que se baseia na necessidade de se ter uma provisão (poupança, reserva) não pela sua necessidade objetiva, certa (imediata ou futura), mas pela possibilidade subjetiva desta necessidade (ela pode ser criada ou ocorrer de uma hora para outra), no sentido de formal e de escassez. "Uma gestão é formalmente 'racional' na medida em que a 'previdência' essencial em toda economia racional pode exprimir-se, e de fato se exprime em considerações de caráter numérico e calculável" (WEBER, 1999, p.52, grifos do autor). Embora nem toda a ação racional possa ser chamada de 'gestão econômica racional', ela está ligada basicamente a dois aspectos: a) certas utilidades são desejadas pelas pessoas; b) as satisfações destes desejos se dão mediante determinadas provisões.

Com relação ao dinheiro, Aristóteles, Simmel e Polanyi o consideram como uma desmaterialização da riqueza enquanto que Weber,, como uma desmaterialização formalizante não só dos bens, mas também das relações de troca: "a forma em dinheiro representa o máximo dessa calculabilidade formal [no sentido de que] do ponto de vista técnico o dinheiro é o meio de cálculo econômico "mais perfeito"”, e a partir do qual o próprio conceito de 'material' adquire caráter formal. (WEBER, 1999, p. 52-53, grifo do autor).

Weber constrói ainda o conceito de 'ação economicamente orientada', com base no qual demonstra a 'invasão' por parte da dimensão econômica em outras dimensões da vida, a partir do predomínio da racionalidade formal/instrumental. Ou seja, para ele a ação é 'economicamente orientada', na medida em que tiver como sentido a obtenção de alguma utilidade.

Diferentemente da gestão econômica, a ação 'economicamente orientada' não se restringe a trocas ou qualquer outra operação de cunho preferencialmente econômico. Uma ação 'economicamente orientada' pode ser, por conseguinte, uma ação não necessariamente econômica, mas em que se considera o aspecto ou a 'situação econômica', como, por exemplo, guerras comerciais, guerras por recursos naturais, disputas políticas ou por poder. Há, portanto, uma instrumentalização da ação e da finalidade em função da finalidade econômica. Nesse sentido, nas guerras, direta ou indiretamente, há sempre motivação econômica, ou seja, trata-se de ações bélicas, mas com finalidades econômicas subjacentes -, conseqüentemente podem ser definidas como ações economicamente orientadas. "[...] a arte da guerra será por natureza e de certo modo uma arte da aquisição" (ARISTÓTELES, 1988, p. 24). Da mesma forma, de acordo com Weber, toda a política racional serve-se também da orientação econômica em seus meios, ao mesmo tempo em que pode estar a serviço de fins econômicos. É o que Gorz (2003, p. 129, citando Thibaud 1984), assinala como uma inversão, referindo-se ao abismo que separa o pensamento liberal da ideologia liberal: "não se trata mais de procurar incluir a economia na sociedade, mas, ao contrário de "desenvolver políticas que incluam a sociedade na economia"'. ${ }^{26}$ A ação

\footnotetext{
${ }^{26}$ Isto pode ser observado claramente na realidade contemporânea e, como exemplo, nas campanhas eleitorais recentes, que mesmo não sendo definidas como ações econômicas, são recheadas de promessas de conteúdo e finalidades de inclusão da sociedade na economia - crescer economicamente; trazer verbas; estimular a produção; gerar empregos e assim por diante -, o que significa dizer
} 
'economicamente orientada' significa, portanto, a penetração, de forma subjacente, da economia em outros campos da vida.

A gestão econômica e a ação econômica, segundo Weber (1999), são fenômenos humanos; esses conceitos significam a impressão do aspecto humano nos objetos e nos processos econômicos, que "adquirem seu caráter como tais unicamente pelo sentido que neles põe a ação humana - como fim, meio, obstáculo ou resultado acessório" (WEBER, 1999, p. 37, grifo do autor). A definição desses dois conceitos - ação 'economicamente orientada' e 'gestão econômica' -, valendo-se da elucidação do sentido conferido a eles pelos indivíduos, tem clara intenção em Weber, qual seja: a de revelar o equívoco da afirmação de que a economia é apenas um 'meio', sem considerar que ela foi subvertida e tornou-se um 'fim'. "Se a economia significa algo, então na prática ela é a escolha previdente entre fins precisamente, ainda que se oriente pela escassez dos meios que parecem disponíveis e acessíveis para estes vários fins" (WEBER, 1999, p. 38, grifos do autor). Nesse sentido, a gestão econômica, é justamente "o grau de cálculo tecnicamente possível que ela realmente aplica", o que Weber define como racionalidade formal, enquanto a racionalidade material é o grande grau de abastecimento de bens de determinados 'grupos' de pessoas, mediante a ação social economicamente orientada por 'postulados valorativos' que constituem o ponto de referência pelo qual este abastecimento é julgado (WEBER, 1999 , p. 38, grifo do autor).

Deste modo, a ação economicamente orientada representa a instrumentalização da ação em função de finalidades materiais e/ou econômicas, enquanto a gestão econômica representa uma racionalidade formal.

De acordo com Gorz (2003), esse processo surgiu com a substituição da ordem tradicional por uma ordem formal, que ocorre com a inserção do dinheiro e do cálculo contábil, o que tornou a racionalidade econômica, acima de tudo, uma variação da racionalidade formal, conforme explicam Mannheim (1962) e Horkheimer (2002). Esta racionalidade posteriormente foi definida como racionalidade instrumental por Ramos (1989) e Gorz (2003) e, incorpora os conteúdos econômicos, tornando-os prioritários. Isto leva a crer que a racionalidade econômica é resultado do cálculo utilitário de conseqüências e das categorias da racionalidade instrumental ${ }^{27}$ (eficácia, rendimento, desempenho). Como bem demonstrou Weber, ela não é a simples ânsia de lucro, pois para se ter êxito econômico é preciso calcular o custo e o ganho de cada ação e de cada operação (construir os meios para os fins determinados). As ações e as operações, por sua vez, só podem ser realizadas graças à racionalização do tempo e da cadeia de atos que configuram a produção, levando em conta as categorias instrumentais.

A racionalidade exposta nas sentenças 'morais' e de 'virtudes' de Benjamin Franklin, citadas por Weber, (1996), por meio das quais ele identifica o seu significado oculto, que é a instrumentalidade, torna-se racionalidade econômica, que se manifesta, portanto, como conseqüência lógica da racionalização da vida essencialmente instrumental. Instrumentalidade esta que é o espírito que impulsionou e orientou o desenvolvimento capitalista ocidental, resultando no industrialismo e no modelo racional orientado prioritariamente para finalidades econômicas, conforme as próprias conclusões de Weber, (1996). O cálculo utilitário de conseqüências transforma-se em cálculo de valores econômicos, como ganhos calculáveis contabilmente. Tempo torna-se dinheiro, solo torna-se dinheiro, capacidades tornam-se dinheiro, e chegamos a um limiar em que bom humor, alegria, saúde, e assim por diante, tornam-se dinheiro.

Autores como Horkheimer, Habermas e Gorz consideram a racionalidade econômica uma variação da racionalidade instrumental. Todavia, a racionalidade econômica, no processo histórico de desenvolvimento do Ocidente, e particularmente no que se refere ao capitalismo e ao industrialismo, tornou-se, com efeito, o conteúdo prioritário da racionalidade instrumental, que passa a operar voltada predominantemente para fins econômicos. Assim, a racionalidade econômica pode ser definida como aplicação da racionalidade instrumental para finalidades de conteúdo predominantemente econômico. No que refere à caracterização deste conteúdo como sendo egoísta ou altruísta, pode-se afirmar que a racionalidade instrumental pode ter fins egoístas ou

que a política e a própria sociedade tornam-se, mais do que em qualquer outra época, uma espécie de subproduto da atividade econômica, evidenciando que a economia conceitualmente não é apenas 'meio', mas, é também - nas práticas acima descritas - 'fim'.

${ }^{27}$ Entendida também como formal ou funcional. 
altruístas, coletivos ou individuais, e os fins econômicos da racionalidade econômica podem ser qualificados como egoístas ou altruístas, sejam estes coletivos ou individuais. Ou seja, o fato de as finalidades serem econômicas não implica automaticamente que sejam egoístas e/ou individuais, embora aumente as possibilidades nesse sentido.

Essa afirmação, portanto, significa, em parte, um desacordo com Souto-Maior, quando, baseado em Simon (1981), afirma que não se deve criticar a racionalidade instrumental e, sim a racionalidade econômica, que tem finalidades egoístas e individuais. Contudo, a crise da razão desvelada pelos autores discutidos nas sessões supra merece, sim, as críticas axiomáticas recebidas, tanto pela excessiva racionalização da vida (provocada pela predominância da racionalidade instrumental em detrimento de outras racionalidades), enquanto processo histórico e metodológico, como pelo conteúdo econômico que a abarcou. Nesse sentido, entende-se que qualquer crítica à racionalidade econômica não pode restringir-se ao seu conteúdo, pois também passa pela crítica a esta racionalização excessiva enquanto processo histórico e metodológico.

Se por um lado, conforme afirma Gorz:

A crise da Razão é a crise dos conteúdos irracionais, quase religiosos, sobre os quais se edificou essa racionalização seletiva e particular que é o industrialismo, portador de uma concepção do universo e de uma visão do futuro doravante insustentáveis. (GORZ, 2003, p. 13)

Por outro lado, segundo Ramos (1989), a razão prescreve como os seres humanos deveriam ordenar sua vida pessoal e social, e na 'sociedade moderna' esta opera predominantemente com base em critérios da racionalidade instrumental e de conteúdo econômico. Em outras palavras, a racionalidade instrumental produziu uma forma particular de racionalidade, a racionalidade econômica, cujo fim é o funcionamento racional de sistemas de meios tendo em vista a acumulação (econômica) de mais meios com a finalidade do lucro (GORZ, 2003). O lucro, por sua vez, torna-se novamente meio que gera mais lucro, e assim por diante. Colocam-se, aí, em prática, as virtudes e a moral de Benjamin Franklin, em que dinheiro gera dinheiro. "[A partir disso] o ser humano se tornou senão uma criatura capaz do cálculo utilitário de consequiências, e o mercado [a economia] o modelo de acordo com o qual a sua vida associada deveria organizar-se" (RAMOS, 1989, p. 22). É o que Gorz (2003) intitula de "isso me basta" a "quanto mais, melhor", que é a passagem de uma racionalidade de subsistência para uma racionalidade mercadológica. "As coisas mudam a partir do momento em que não produzo mais para o autoconsumo, mas para o mercado" (GORZ, 2003, p.109, grifo do autor). E as ações econômicas deixam de ser ações para suprir necessidades, tornando-se ações com finalidades econômicas, num ciclo em que a economia deixa de ser um ‘meio' para tornar-se um ‘fim’ em si mesma.

\section{Conclusão: crítica à racionalidade econômica e ao industrialismo}

"É preciso racionalizar a própria racionalização [...] [porque] a racionalização transforma-se no seu exato oposto" (grifo do autor). Essa citação de Gorz parece extremamente adequada como crítica ao processo de racionalização da vida, em função da racionalização da produção até aqui discutida, assim como para iniciar uma crítica à razão econômica, tal como a empreendida por ele. Para Gorz, a crise da razão é uma crise dos motivos e conteúdos irracionais, agora visíveis, da racionalização irracional. A utopia industrialista que prometia desenvolvimento e emancipação - oferecendo bem-estar, maior liberdade e autonomia e a transformação do trabalho numa atividade autopoiética - encontra-se numa profunda crise, porque a racionalização instrumental da vida se tornou, em última instância, a racionalização econômica da vida. Com base na concepção de economia no seu sentido formal, "fez tábua rasa de todos os valores e fins irracionais do ponto de vista econômico e só mantém, entre os indivíduos, relações monetárias; entre as classes, relações de forças; entre o homem e a natureza uma relação instrumental" (GORZ, 2003 p. 28).

Segundo Gorz (2003), todo esse processo de racionalização formal/funcional - que não se restringe somente às fábricas, mas se estende a todos os demais âmbitos da vida - fez também a separação entre o trabalho do trabalhador e a sua personalidade. Opinião compartilhada por Polanyi (2000), quando afirma que a economia formal separou o trabalho de outras atividades da vida, ao sujeitá-lo às leis do mercado e aniquilar as formas orgânicas da existência, substituindo-as por uma organização atomista e individualista. Só assim foi possível a 
padronização não somente dos produtos, como também dos trabalhadores, levando ao que Gorz denomina de reificação (coisificação) do trabalho, do trabalhador e de todas as relações. "[A racionalidade econômica] vem 'colonizar', reificar e mutilar até mesmo o tecido relacional do qual dependem a integração social, a educação e a socialização dos indivíduos" (GORZ, 2003, p. 107). É o que Illich (1976) denomina de desnaturalização da natureza e que constitui o desenraizamento do homem, a perda da espontaneidade e a castração da sua criatividade. Essa desnaturalização ocorre na fase avançada da produção em massa, na qual a sociedade gera a própria destruição, na medida em que transforma o homem em matéria-prima, desintegrando-o, promovendo a degradação da natureza e a destruição dos laços sociais. Como observa Polanyi (2000, p. 61), "a produção é a interação do homem com a natureza", e quando esse processo é submetido quase que exclusivamente ao mecanismo auto-regulador da economia de mercado, tanto o homem, como a natureza, tornam-se mercadorias e são tratados como bens produzidos para venda, num processo que transforma a substância natural e humana da sociedade em mercadorias. "O homem, sob o nome de mão-de-obra, e a natureza, sob o nome de terra [e recursos naturais], foram colocados à venda" (POLANYI, 2000, p.162).

Esta racionalidade, por muito tempo, foi contida, não apenas pela tradição, mas também por outros tipos de racionalidade, finalidades e interesses que lhe impunham limites (GORZ, 2003). Contudo, como observou Weber, a redução da religiosidade e de uma série de outras crenças e tradições antigas, que foram deixadas para trás ou destruídas devido a uma inversão que colocou no seu lugar a produção de dinheiro como a finalidade última da vida, fez surgir inevitavelmente a burguesia dominada pela 'racionalidade econômica'. "O capitalismo industrial só pôde desenvolver-se a partir do momento em que a racionalidade econômica emancipou-se de todos os outros princípios de racionalidade, para submetê-los a seu único domínio" (GORZ, 2003, p. 27). Da mesma forma, a indústria só pôde nascer graças à racionalização formal e, conseqüentemente, econômica do trabalho. O resultado dessa racionalização capitalista, em sua funcionalidade, é a transformação da natureza em algo sem vida, senão apenas fonte de recursos para sustentar a produção e seus agentes, cujas faculdades são mirradas e mutiladas, tornando-se embrutecidos pelo trabalho, porque transformados em engrenagens funcionais sem vida, perdendo, assim, a consciência reflexiva das próprias atividades exercidas (GORZ, 2003, p. 27). É a separação do trabalhador do fruto do seu trabalho em nome da conduta funcional, como observou Marx (2000).

Gorz, a exemplo de Mannheim, chama de funcional a conduta que é racionalmente adaptada a um fim, independentemente da intenção ou da consciência do agente, que muitas vezes a desconhece.

A funcionalidade é uma racionalidade externa trazida a uma conduta pré-determinada e prescrita ao ator pela organização que o envolve. Tal conduta é a função que tem a desempenhar, sem discutir seus objetivos. Quanto mais ela se desenvolve, mais a organização tende a funcionar como uma máquina. (GORZ, 2003, p. 39, grifo do autor)

É com base nesta funcionalidade que a racionalização econômica do trabalho foi além da organização da produção. Valendo-se dos princípios da racionalidade instrumental, ela gerou, conforme Gorz, uma subversão do modo de vida, dos valores, das relações sociais e das relações com a natureza como jamais ocorrera antes, fazendo surgir um indivíduo alienado, não só no que se refere ao seu trabalho como também às suas necessidades e ao seu consumo: $:^{28}$

A racionalização econômica do trabalho venceu, portanto, a resistência das antigas idéias de liberdade e de autonomia existenciais. Fez nascer o indivíduo que, alienado em seu trabalho, também o será, obrigatoriamente em seu consumo e, finalmente, em suas necessidades. (GORZ, 2003, p. 31)

"O preço que os homens pagam pela multiplicação do seu poder é a sua alienação daquilo sobre o que exercem o poder" (ADORNO; HORHEIMER, 2000, p. 24). Essa alienação foi, e é, condição necessária para o desenvolvimento e manutenção da racionalidade econômica, que não pode ser aplicada, nas palavras de Gorz,

\footnotetext{
${ }^{28}$ De acordo com Gorz, o socialismo tentou reverter esse processo de alienação, sem sucesso, pois a consciência reflexiva da sociedade continuou sendo uma 'consciência externa, separada', nas sociedades onde se empreendeu o socialismo, tal como nas sociedades capitalistas. Ou seja, a moral socialista apresentava uma semelhança muito grande com a ética protestante, com a diferença de que na ascese puritana a motivação estava na fé de que o trabalho servia para a glória de Deus, enquanto no socialismo esta motivação estava na fé no próprio trabalho como forma de realizar o Plano representado pelo Partido.
} 
"quando o indivíduo é livre para determinar por si só o nível de suas necessidades e o nível de esforço que despende" (GORZ, 2003, p. 112).

Para Illich (1976), o indivíduo, uma vez modelado na mentalidade de consumidor-usuário, perde a capacidade de ver a perversão dos meios voltados para fins da manutenção da estrutura da produção industrial, assim também como do que é necessário e do que é excessivo, agarrando-se à idéia de que o aumento do salário corresponde ao aumento do nível de vida. Conforme os preceitos da racionalização da vida em que o 'meio' torna-se 'fim', o homem moderno não consegue conceber o desenvolvimento e a modernização em termos de redução senão como crescimento e consumo de energia, e de toda ordem de coisas, associando o grau de cultura ao alto consumo. A ideologia da organização industrial, da instrumentalização, da produtividade estandardizada e da organização capitalista da economia, portanto, mina o equilíbrio qualitativo, estabelecendo bases quase que exclusivamente quantitativas, conforme observou Simmel (1903).

Dito de outro modo, conforme Gorz, na medida em que evolui a racionalização, também ocorre a 'eliminação do fator humano' e a sua substituição por um trabalhador programado, como uma exigência da racionalidade econômica e da racionalidade funcional/formal, que, por sua vez, prescindem da consciência profissional dos trabalhadores, assim como de qualquer espírito de cooperação.

A tecnicização, a reificação, a monetarização das relações encontram sua âncora cultural nessa técnica de pensar cujas operações funcionam sem a implicação do sujeito e da qual os sujeitos, ausentes, são incapazes de dar conta de si mesmos. (GORZ, 2003, p. 126)

A consciência desse trabalhador, em relação às suas atividades produtivas, passa a restringir-se à finalidade única de se obter um salário. "O que conta é o pagamento que cai no fim do mês", conforme reza o dito popular. Esse é o universo da sua consciência, o trabalho e o salário como meios para o consumo. Surge assim o trabalhador-consumidor como duas faces indissociáveis de uma mesma categoria.

O trabalhador funcional que aceita ser alienado em seu trabalho porque suas possibilidades de consumo oferecem-lhe suficientes compensações, um tal trabalhador funcional só pode surgir caso surja, simultaneamente, como sua outra face, o consumidor socializado. (GORZ, 2003, p. 52)

Este consumidor socializado e a contabilidade que opera com as noções de 'mais' e de 'menos', mas que desconhece a noção de 'suficiente', são as condições necessárias à expansão da racionalidade formal, levando a uma inevitável inversão: a do consumo sem limites a serviço da produção também sem limites.

Entretanto, com efeito, a consequiência dessa falta de limites ao consumo e à produção imposta pela racionalidade econômica, que impera pela falta de outras racionalidades, é "caminhar em direção à desintegração completa da sociedade e à destruição irreversível da biosfera" (GORZ, 2003, p. 129). Desse modo, sem outros critérios de racionalidade, a economia tem grande chance de "evoluir inexoravelmente em direção ao colapso" (GORZ, 2003, p. 131), ocasionado, principalmente, segundo afirma Illich (1976, p. 23), porque "o domínio do homem sobre a ferramenta foi substituído pelo domínio da ferramenta sobre o homem". 29 Durante mais de um século a humanidade se desenvolveu baseando-se na hipótese de que a 'ferramenta' poderia substituir o escravo, sem se aperceber, no entanto, que se tornava escrava da 'ferramenta'. Neste mesmo sentido, para Horkheimer (2002), quanto mais inventamos artifícios para explorar e dominar a natureza, mais temos que nos submeter a esses artifícios de dominação e às próprias conseqüências que geram na natureza. É o que ele chama de revolta da natureza. Esse paradoxo se deve ao fato de se ter atingido níveis impensáveis de habilidade de instrumentalizar a ação humana, ao mesmo tempo em que é cada vez mais difícil recuperar a espontaneidade e o controle pessoal das próprias ações. "A instituição industrial tem uns fins que justificam os meios. O dogma do crescimento acelerado justifica a sacralização da produtividade industrial à custa da convivencialidade" ${ }^{30}$ (ILLICH 1976, p. 25).

\footnotetext{
${ }^{29}$ Illich usa o termo 'ferramenta' como uma categoria que abrange todos os instrumentos da ação humana e no sentido de 'meios' racionais, justificados pelos fins do industrialismo, num sentido coerente com a racionalização supra.

${ }^{30}$ Por convivencialidade, Illich entende o inverso da produtividade industrial. Ele afirma que "a passagem da produtividade para a convivencialidade é a passagem da repetição da carência para a espontaneidade" (ILLICH, 1976, p. 25).
} 
Esta industrialização, por sua vez, provoca sua própria instabilidade pelo fato de que se desenvolve em perspectivas de racionalização (materializando inclusive valores) e crescimento indefinidos, ocasionando e, ao mesmo tempo, ignorando tanto a degradação social como a ambiental. Illich (1976), citando Ehrlich, afirma que a única esperança da humanidade, no que se refere ao controle da crise ambiental e da miséria, é uma mudança cultural que passe pelo controle populacional aliado a uma redução do consumo, este último com consequiências diretas sobre a concepção de produção industrial. Illich é crítico do que ele chama de remédios milagrosos, que pretendem conjugar desenvolvimento industrial com sobrevivência em eqüidade, e afirma que é ilusório esperar que a ação humana instrumentalizada possa caminhar nessa direção. Ao contrário, aponta que a restauração de um equilíbrio ecológico, que entendemos como equilíbrio sócio-ambiental, "depende da capacidade do corpo social para reagir contra a progressiva materialização dos valores, na sua transformação em áreas técnicas" (ILLICH 1976, p. 69).

Ou seja, sem a libertação da jaula da instrumentalização e da racionalidade econômica ou, como define Weber (1996), uma prisão gerada pelo mecanicismo sem espírito, torna-se impossível restabelecer o equilíbrio sócioambiental, pois o desequilíbrio no qual a humanidade e o planeta se encontram hoje é um dos produtos da humanidade racionalizada e dominada pelo economicismo. É o que Polanyi (2000) observa como a subordinação do homem e da natureza aos mecanismos da economia de mercado, que alienam o homem em relação à consciência de que sociedade e natureza fazem parte de um todo articulado. O primeiro passo, portanto, para restabelecer esse equilíbrio é o reconhecimento de que só a humanidade pode fazê-lo, a partir da recuperação de sua consciência. E só o fará se resgatar outros critérios de racionalidade que não sejam a intrumentalização e o economicismo, gêneses de grande parte dos problemas contemporâneos, tais como a degradação da qualidade de vida, a poluição, o desperdício, a exaustão dos recursos naturais, a pobreza (RAMOS, 1989). Portanto, critérios substantivos, diferentes daqueles da racionalidade social, essencialmente voltada para valores de cunho economicista e utilitarista, que sustenta, conforme observa Leff (2001), todos os âmbitos da organização social: do modelo de produção e de consumo até ao próprio Estado. 


\section{Referências}

ADORNO, T. W.; HORKHEIMER, M. Conceito de lluminismo. São Paulo: Nova Cultural, 2000. (Coleção Os Pensadores: Textos escolhidos).

ARISTÓTELES. Política. Brasilia: UnB, 1985.

COHN, G. Max Weber: Sociologia. São Paulo: Ática, 1989.

FERNANDES, V. A dimensão ambiental em organizações produtivas: uma análise da racionalidade da economia de comunhão (EDC). Florianópolis, 2007. 183 f. Tese (Doutorado) - Universidade Federal de Santa Catarina, Centro Tecnológico. Programa de Pós-Graduação em Engenharia Ambiental.

FERREIRA, A. B. H. Dicionário Aurélio eletrônico século XXI - versão 3.0. São Paulo: Nova Fronteira, 1999. 1CD ROM.

GORZ, A. Metamorfoses do trabalho: critica da razão econômica. São Paulo: Annablume, 2003.

HABERMAS, J. Teoría de la acción comunicativa: complementos y estudios previos. Madri: Cátedra/Teorema, 1994.

HOBBES, T. Leviatã ou matéria, forma e poder de um Estado eclesiástico e civil. São Paulo: Nova Cultural, 2000. (Coleção Os Pensadores: textos escolhidos)

HORKHEIMER, Max. Eclipse da razão. São Paulo: Centauro, 2002.

ILLICH, Ivan. A convivencialidade. Lisboa: Europa-América, 1976.

LEFF, Enrique. Epistemologia Ambiental. São Paulo: Cortez, 2001.

LISBOA, A. M. A Crítica de Karl Polany à utopia do mercado. Lisboa: Instituto Superior de Economia e Gestão, Universidade Técnica de Lisboa. Centro de Investigação em Sociologia Econômica e das Organizações. Working Papers, 2000.

MANNHEIM, K. 0 homem e a sociedade: estudos sobre a estrutura social moderna. Rio de Janeiro: Zahar, 1962.

MARX, K. 0 rendimento e suas fontes. São Paulo: Nova Cultural, 2000. (Coleção Os Pensadores: textos escolhidos) p. 188-254).

POLANYI, K. A grande transformação: as origens da nossa época. Rio de Janeiro: Editora Campus, 2000.

El sustento del hombre. Barcelona: Mondadori, 1994.

RAMOS, A. G. A nova ciência das organizações: uma reconceituação da riqueza das nações. Rio de Janeiro: Fundação Getulio Vargas, 1989.

SACHS, I. Espaços, tempos e estratégias do desenvolvimento. São Paulo: Vértice, 1986.

Estratégias de transição para o século XXI: desenvolvimento e meio ambiente. Studio Bobel: FUNDAR, 1993.

SIMMEL, G. A chapter in the philosophy of value. Chicago: American Journal of Sociology, v. 5, 1900. Disponivel em: <http://socserv2.socsci.mcmaster.ca/ econ/ugcm/3/l3/simmel/value>. Acesso em: 30 ago. 2006.

SIMMEL, G. As grandes cidades e a vida do espírito (1903). Mana, Rio de Janeiro, v. 11, n. 2, 2005. Disponível em: http://test.scielo.br/scielo.php?script=sci_arttext\&tpid=S0104-93132005000200010\&tlng=es\&tnrm=iso>. Acesso em: 03 ago. 2006.

SIMMEL, Georg. Filosofia del dinero. Madrid, 1977.

SOUTO-MAIOR, J. Racionalidades: alguns esclarecimentos. Estudos Avançados em Administração, v.6, n.2, p.967-991, 1998.

THOREAU, H D. WALDEN ou A vida nos Bosques. São Paulo: Global, 1984.

WEBER, M. A Ética Protestante e o Espírito do Capitalismo. São Paulo: Pioneira, 1996.

. Economia e sociedade: fundamentos da sociologia compreensiva. Vol. 1. Brasilia: Unb, 1999.

WIKIPÉDIA. Benjamin Franklin. <Disponivel em: http://pt.wikipedia.org/wiki/Benjamin_Franklin>. Acesso em: [Acesso em: 10 de julho. 2006. ] 